\section{Preventing and identifying Scientific Fraud in Tree Science Research, with specific reference to World Agroforestry Centre (ICRAF)}

Richard Coe, Flemming Nielsen, Meine van Noordwijk and Tony Simons 



\section{Preventing and identifying Scientific Fraud in Tree Science Research, with specific reference to World Agroforestry Centre (ICRAF)}

ICRAF operates a 'Zero-tolerance' policy on the manipulation of financial and scientific data. Here we focus on the misrepresentation of scientific data, or 'Scientific Fraud'. The purpose of this paper is mainly to protect the innocent by helping everyone understand what can happen and how it can be avoided.

Richard Coe, Flemming Nielsen, Meine van Noordwijk and Tony Simons

June 2009 


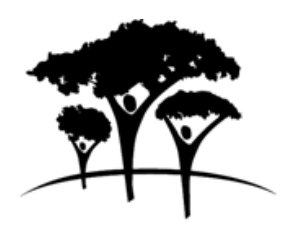

World Agroforestry Centre

TRANSFORMING LIVES AND LANDSCAPES

Correct citation: Coe R, Nielsen F, van Noordwijk M, Simons T. 2009. Preventing and identifying Scientific Fraud in Tree Science Research, with specific reference to World Agroforestry Centre (ICRAF). ICRAF Working Paper no. 88. Nairobi, Kenya: World Agroforestry Centre.

Titles in the Working Paper Series aim to disseminate interim results on agroforestry research and practices and stimulate feedback from the scientific community. Other publication series from the World Agroforestry Centre include: Agroforestry Perspectives, Technical Manuals and Occasional Papers.

Published by the World Agroforestry Centre

United Nations Avenue

PO Box 30677, GPO 00100

Nairobi, Kenya

Tel: +254(0)20 7224000, via USA +1 6508336645

Fax: +254(0)20 7224001, via USA +1 6508336646

Email: icraf@cgiar.org

Internet: www.worldagroforestry.org

(C) World Agroforestry Centre 2009

Working Paper no. 88

The views expressed in this publication are those of the authors and not necessarily those of the World Agroforestry Centre.

Articles appearing in this publication may be quoted or reproduced without charge, provided the source is acknowledged.

All images remain the sole property of their source and may not be used for any purpose without written permission of the source. 


\section{Contents}

Introduction 1

What is Fraud? 2

Why does it happen? 2

Checking the data 4

Preventing the problem from arising $\quad 4$

Consequences of fraud and action to take 6

What to do if you suspect fraud 6 


\section{Introduction}

Science is often said to bar dishonesty and bad research with a triple safety net. The first is peer review, in which experts advise funders about what research to finance. The second is the referee system, which has journals ask reviewers to judge if manuscripts merit publication. The last is replication, whereby independent scientists see if the work holds up.

Even the most prestigious scientific journals, with the most rigorous systems of peer review, have had the unpleasant experience of having to withdraw publications on 'new' findings, that were based on falsified or dubious data. For example, the journal Science (Volume 289, 18 August 2000) retracted a paper previously published by the journal after it was found that one of the authors had falsified data. The significance of this is discussed in a thoughtful piece by Donald Kennedy in the same issue (p1137). He makes the point that every case of this type damages the reputation not only of the people and institutes involved, but, in the eyes of our public patrons, science and scientists generally. The Science case is not unique. A laboratory in Europe has recently had to retract hundreds of papers and around the world there are numerous cases being investigated.

Within ICRAF, and in many of our partner institutes, there seem to be two contradictory experiences. On the one hand there is the view that scientific fraud - the deliberate use of false data with intention to mislead - does not happen in serious scientific institutes. Apart from a few well-publicized cases (cigarette damage, Piltdown Man, stem cells, perhaps cold fusion), basic scientific ethics would prevent anyone from deliberately fabricating evidence. On the other hand many scientists have had personal experiences in which they discovered or strongly suspected that data had been falsified. However, if these cases are not openly discussed, the correct reaction of the institute is not understood and there is no discussion of the reasons for fraud occurring nor putting in place mechanisms and systems to reduce likelihood of future fraud.

The aim of this discussion paper is to change this situation by promoting discussion of the topic of fraud in science in ICRAF. The objectives are:

- to alert scientists to the possibility of fraud.

- to suggest reasons why it happens.

- $\quad$ to suggest steps to avoid it.

- to make sure everyone is aware of ICRAF's policy on fraud and action to take if it is discovered.

In this paper we are focusing on deliberate attempts to falsify or misrepresent data. Other science practices that many consider fraudulent or unethical are discussed elsewhere. Note that some of these may be a surprise to many. In a recent example, claiming that papers had been submitted for publication before they actually had been was judged fraudulent and led to research funding being terminated.

This paper is not a comprehensive review of scientific fraud. If you want to read more a good starting point would be the bibliography at:

http://www. chem.vt.edu/chem-ed/ethics/index.html

A very interesting discussion list is SCIFRAUD. For information send an email to LISTSERV@LISTSERV.ALBANY.EDU with the message: info SCIFRAUD

A broad article with definitions and cases can also be found at http://en.wikipedia.org/wiki/Scientific_misconduct 


\section{What is Fraud?}

Practices that are indisputably fraudulent are easy to identify, and can occur at many steps of the research process. Raw data can be falsified in the field or laboratory as they are collected, or can even be made up beforehand 'under a mango tree'. Data can be further falsified as results are processed or presented in tables and graphs. Fraud can occur not just by falsification of the numbers but by deliberately changing the protocol, arbitrarily eliminating non-supporting data or misrepresenting the processes used. By strict definition some even define fraud as showing only a very small part of a photograph in a powerpoint so that additional information is not visible.

The limits to what is fraudulent are difficult to define. For example, analysing and reporting only part of the data collected, or deliberately omitting individual observations from analysis, may be good practice or may be a deliberate attempt to deceive. The distinction probably lies in the reasons why data have been filtered and the openness with which the methods are described. Similarly ambiguous is the quoting of results that are generated by a vague estimation process rather than by a well defined data collection activity. It is acceptable, and useful, to use such 'guestimates' in many situations but fraudulent to present them in a way that implies they come from a verifiable, objective or repeatable research process. Omitting to investigate suspected bias and/or report it is fraudulent. An example is the so-called "road-side" bias where interviews or crop sampling is conducted close to access roads for logistical reasons, but this has not been explained.

Another practice that is sometimes regarded as fraudulent is that of 'honorary authorship'. This is the inclusion as authors of a publication people who did not make a direct contribution to the research reported, but are listed for political reasons. This and other ethical issues concerning publication and ownership of data are discussed in other policy documents.

\section{Why does it happen?}

In an insightful article, Goodstein (http://www.its.caltech.edu/ dg/conduct_art.html) identifies 3 common characteristics of scientists who commit fraud:

1. They are under career pressure. There is seldom a simple monetary gain involved, but they feel under some pressure to produce results.

2. They know, or think they know, how the answer will turn out if the research is completed properly. While bending the rules of science, they believe they are not perverting the knowledge base.

3. They work in a field where individual experiments are not expected to be precisely reproducible, reducing the chance of detection.

All these can apply at ICRAF so we should consider ICRAF scientists at (relatively) high risk of temptation. We have identified two additional risk factors that are more applicable to the technicians and staff assisting scientists:

4. Lack of motivation.

5. Unreasonable requests or workloads imposed by supervisors (including fear of non-delivery).

Lack of motivation is often caused by lack of understanding of the reasons for, and importance of, the work being carried out. It is easy to see why staff who have carried out similar measurements or interviews hundreds of times without knowing the objectives of the research are tempted to make shortcuts. Further, if they get the impression that no one is actually using the data collected, it may be easy to take the decision to fake it. 


\section{Example 1}

The technician told the researcher that the trees he wanted to use for the experiments on Pollination Effectiveness were not currently flowering in the field, but the researcher asked her/him to go back and try once more, as (s)he needed to finish the experiment before the grant would run out. The technician came back with pollen, and the experiment was done, concluding that Pollination Effectiveness was very low. Results were submitted to a journal, but internal reviewers became suspicious. The technician finally admitted that short cuts had been used to satisfy the urges of the respected researcher, and maize rather than tree pollen had been provided.

Recently in ICRAF there has also been discussion of the workloads and pressure that senior staff are subjected to. The possibility that this can also lead to fraud must not be discounted. Use of quantitative targets for work, such as the numbers of farmers that ICRAF intends to reach in the medium term, certainly helps scientists to focus, perhaps improving efficiency. However it has also led to the use of vague and over-optimistic estimation procedures. The boundary between that and fraud is not clear, but the discredit that such practices can bring to a centre are equally damaging.

\section{Example 2}

A project had set a target of 40,000 farmers using a new technology by the end of Year 3 . At Year 1 there were 10,000 counted, with 20,000 at the end of Year 2. Year 3 data did not look so promising. But the Project Coordinator knew there had been lots of activity in Year 3, so 'guessed' there must be 40,000 and reported that to donors.

\section{Example 3}

Analysis of recent data showed some interesting trends, but the statisticians advised that further data would be needed before firm conclusions could be drawn. The researcher was convinced that (s)he knew the answer anyway, but applied for funding to collect these data. Some things went wrong at home and there were more urgent needs for the money than extensive field trips that would lead to data that (s)he believed were quite predictable anyway. So - the data set was enlarged rapidly and money saved for other uses. Unfortunately the statistician became suspicious...

It is clear that pressure to produce results filters throughout the institute, with scientists making unreasonable requests of field staff. The time pressure everyone feels can mean that senior staff do not spend sufficient time in the field or laboratory, and get out of touch with the requirements of a task. Eventually this leads to work schedules that can not possibly be met, resulting in a strong incentive to take short cuts.

\section{Example 4}

A senior scientist was writing up results of an important trial with collaborators. The results were contrary to expectations and suggested much earlier work had been a waste of time. The work had been given a high profile and now it looked as if expectations of important stakeholders would not be realised. The data looked much more promising if numbers in some key tables were switched around, so (s)he did this, even though there was no indication that data had in fact got mixed up. 


\section{Checking the data}

A determined fraudster who understands the nature of data from their type of research can always make up numbers that look real. Luckily many people are not this able and fake data can be spotted, but only if looked for. Any supervisor should look at data collected by staff, scrutinizing both raw field (or lab) results and processed or summarised observations. It is important that this is done very soon after data collection so that it is possible to follow up on anything that looks wrong.

Things to look for in raw data include:

- Observations which seem at odds with the protocol.

- Observations which are internally inconsistent.

- Observations which are less variable than expected.

- 'Observations' which have a fixed ratio with other data and might have been calculated rather than measured.

The actual data recording process can also be checked, going back to raw data recording sheets and samples. Look out for:

- Field or lab record sheets that are spotless.

- Poorly or ambiguously labelled data sheets.

- Unexpectedly complete datasets (where at least a few missing values would be expected).

- Excessive data recorded in a single day or recording period.

- Missing data sheets but present result tables.

It is also necessary to carry out a check of the processed data, including tables of means and variances, relationships between different quantities etc. The points to look for are:

- $\quad$ Results that are less variable than expected.

- Inconsistencies when the same data appear in different tables, graphs or reports.

- Results that contradict known processes.

Of course there may be many reasons why data may look 'odd', from simple mistakes made with no intention to mislead, to the protocol being changed for good reason, or our preconceptions of what the data should look like being wrong - in fact that is when we really learn something in science! Fraud is actually the least likely explanation for the 'odd' data, but whatever the reason it is important for a supervisor to note that there is something that needs follow-up, and to do that thoroughly and sensitively.

\section{Preventing the problem from arising}

While the checks on data outlined above may help detect fraudulent data, we have to aim at preventing it in the first place, thereby avoiding all the costs that fraud incurs. This is a rule of any quality management. In this case there are several simple steps that can certainly reduce the risk.

Every supervisor has a responsibility to motivate staff by making sure they understand the context and reasons for the work. Senior staff in ICRAF are routinely involved in discussions of strategies and impact, but to field staff the work can often seem as just another 2 weeks to be spent tramping round asking farmers the same old questions. Encouraging staff to provide feedback on the data collection process and any anomalies they notice also leads to better insights and shows interest. 
Feedback to all levels of staff is important for sustaining a high level of motivation. Lack of feedback during data collection easily leads to the impression that it does not really matter what data is provided to the researcher. Immediate feedback requires the active involvement of the scientists at the time of data collection. If the scientist is seen in the field taking an active interest in both the data collection process and the results, field staff may be convinced of its value. Feedback also requires speedy data processing. It is not unusual that data are being processed months or years after they were collected. This not only means data collectors get the impression that it is unimportant, but also that any queries that arise when data are eventually analysed can not be followed up. Junior staff are rarely informed about the outcome of their work (articles, presentations, new projects, etc.) further reinforcing the impression that it doesn't really matter what data they provide to the scientists.

\section{Example 5}

An unusually careful researcher was collecting data in a large farm survey, using a large team of enumerators. As part of the quality control process, he revisited a sample of farms from which data had reportedly been collected. He found that some of those farms had not actually been visited by enumerators.

Quality checks are notoriously difficult in off-station work, such as in on-farm experiments and social surveys. A pre-condition for detecting fraud is that the scientist in charge understands the practicalities of the work involved. For instance, if the scientist knows from experience that it takes an hour to carry out one interview then s/he will know that something is wrong if an assistant hands in twenty questionnaires daily. In some cases enumerators have been paid according to the number of completed questionnaires returned, with an obvious incentive to fake data. Performance-based salary systems should never be applied without sufficient checks in place.

Supervisors also need to be familiar with field operations to make sure they are not making unrealistic requests. A few days with a field team gives a supervisor invaluable insight into what works well, what may be error prone, and what it is reasonable to require staff to do. In other research areas very senior staff often maintain a research activity of their own so that they spend time in the field or lab, keeping track of who and what works well.

Feedback of compiled results, their implications, and the way they will be used is also important. Eventually field staff should see copies of annual reports and other publications. However draft reports, or feedback on the way the work has been received elsewhere, also help.

The same ideas apply when thinking of senior scientists and removing any motivation they have to practise fraud. ICRAF has to provide a working environment that encourages innovation, efficiency and impact without undue pressures building up. It has to ensure that results that fail to match expectations or do not confirm early optimistic predictions are valued as highly as those that promise large impact, as long as the work has been well conducted. It has to cultivate an institutional culture and reputation for integrity and responsibility, as well as for innovation and a challenging vision. If management structures are working well and everybody is communicating with supervisors then problems should be resolved long before anyone feels pushed to make up results. 


\section{Consequences of fraud and action to take}

In principle, science is 'self correcting' - false results will, eventually, be found to be so and be replaced with correct information. This will take time, and in the interim there could be grave consequences of false information being passed to clients, and a substantial waste of time and money. Once fraud is exposed the effect on the credibility of the institute, partners and all individuals involved is obvious.

For these reasons, ICRAF's policy towards individuals found to be deliberately falsifying results is clear and strict. Although scientific fraud is not explicitly mentioned currently in the Personnel Policy Manual (a case of assuming it won't happen?) it is covered under the grounds for disciplinary action as:

- Gross negligence.

- $\quad$ Fraud or dishonesty involving ICRAF.

- $\quad$ Actions that bring ICRAF into disrepute.

The result is that those found guilty of fraud can expect to be summarily dismissed. In addition ICRAF may press criminal charges of fraud if appropriate.

The supervisors of those practicing fraud also bear some responsibility. It seems to be widely believed that'I cannot be held responsible for something I don't know about'. However if it has been possible for the fraud to occur because supervision has been lax, then the supervisor is guilty of negligence. For example, a supervisor who never looks at raw data generated or never observes field data collection activities may not be using appropriate levels of supervision and so is, to some extent, also responsible for the fraud.

\section{What to do if you suspect fraud}

If you find a case of suspected fraud within ICRAF then the following steps should be taken:

1. Preserve the evidence that you feel substantiates the fraud.

2. Inform the direct supervisor of the suspicion, together with the relevant program leader, regional coordinator and director.

3. The supervisor then has to organise an investigation that establishes whether fraud has been committed and the extent to which fraudulent information has been used and published.

4. The report from this investigation is given to the Director General who will follow normal disciplinary processes as appropriate. Note that the Personnel Policy Manual includes a provision for staff to be suspended during an investigation.

5. The supervisor has to carry out comprehensive removal of fraudulent information from databases and reports. If fraudulent information has been published then the paper must be retracted. If significant fraudulent information has been included in reports to donors then they have to be informed.

All staff accused of fraud however are innocent until proven guilty. Whistleblowers or data scrutineers also have to be highly valued by all staff as they help us sharpen our practice and maintain our reputation. 


\section{WORKING PAPERS IN THIS SERIES}

1. Agroforestry in the drylands of eastern Africa: a call to action.

2. Biodiversity conservation through agroforestry: managing tree species diversity within a network of community-based, nongovernmental, governmental and research organizations in western Kenya.

3. Invasion of prosopis juliflora and local livelihoods: Case study from the Lake Baringo area of Kenya.

4. Leadership for change in farmers organizations: Training report: Ridar Hotel, Kampala, 29th March to 2nd April 2005.

5. Domestication des espèces agroforestières au Sahel : situation actuelle et perspectives

6. Relevé des données de biodiversité ligneuse: Manuel du projet biodiversité des parcs agroforestiers au Sahel.

7. Improved land management in the Lake Victoria Basin: TransVic Project's draft report.

8. Livelihood capital, strategies and outcomes in the Taita hills of Kenya.

9. Les espèces ligneuses et leurs usages: Les préférences des paysans dans le Cercle de Ségou, au Mali.

10. La biodiversité des espèces ligneuses: Diversité arborée et unités de gestion du terroir dans le Cercle de Ségou, au Mali.

11. Bird diversity and land use on the slopes of Mt. Kilimanjaro and the adjacent plains, Tanzania.

12. Water, women and local social organization in the Western Kenya Highlands.

13. Highlights of ongoing research of the World Agroforestry Centre in Indonesia.

14. Prospects of adoption of tree-based systems in a rural landscape and its likely impacts on carbon stocks and farmers' welfare: The FALLOW Model Application in Muara Sungkai, Lampung, Sumatra, in a 'Clean Development Mechanism' context.

15. Equipping integrated natural resource managers for healthy Agroforestry landscapes.

16. Are they competing or compensating on farm? Status of indigenous and exotic tree species in a wide range of agro-ecological zones of Eastern and Central Kenya, surrounding Mt. Kenya.

17. Agro-biodiversity and CGIAR tree and forest science: approaches and examples from Sumatra.

18. Improving land management in eastern and southern Africa: A review of policies.

19. Farm and household economic study of Kecamatan Nanggung, Kabupaten Bogor, Indonesia: A socio-economic base line study of Agroforestry innovations and livelihood enhancement.

20. Lessons from eastern Africa's unsustainable charcoal business.

21. Evolution of RELMA's approaches to land management: Lessons from two decades of research and development in eastern and southern Africa.

22. Participatory watershed management: Lessons from RELMA's work with farmers in eastern Africa.

23. Strengthening farmers' organizations: The experience of RELMA and ULAMP.

24. Promoting rainwater harvesting in eastern and southern Africa.

25. The role of livestock in integrated land management.

26. Status of carbon sequestration projects in Africa: Potential benefits and challenges to scaling up.

27. Social and Environmental Trade-Offs in Tree Species Selection: A Methodology for Identifying Niche Incompatibilities in Agroforestry [Appears as AHI Working Paper no. 9].

28. Managing tradeoffs in agroforestry: From conflict to collaboration in natural resource management. [Appears as AHI Working Paper no. 10].

29. Essai d'analyse de la prise en compte des systemes agroforestiers pa les legislations forestieres au Sahel: Cas du Burkina Faso, du Mali, du Niger et du Senegal.

30. Etat de la recherche agroforestière au Rwanda etude bibliographique, période 1987-2003.

31. Science and technological innovations for improving soil fertility and management in Africa: A report for NEPAD's Science and Technology Forum. 
32. Compensation and rewards for environmental services.

33. Latin American regional workshop report compensation.

34. Asia regional workshop on compensation ecosystem services.

35. Report of African regional workshop on compensation ecosystem services.

36. Exploring the inter-linkages among and between compensation and rewards for ecosystem services CRES and human well-being.

37. Criteria and indicators for environmental service compensation and reward mechanisms: realistic, voluntary, conditional and pro-poor.

38. The conditions for effective mechanisms of compensation and rewards for environmental services.

39. Organization and governance for fostering Pro-Poor Compensation for Environmental Services.

40. How important are different types of compensation and reward mechanisms shaping poverty and ecosystem services across Africa, Asia \& Latin America over the Next two decades?

41. Risk mitigation in contract farming: The case of poultry, cotton, woodfuel and cereals in East Africa.

42. The RELMA savings and credit experiences: Sowing the seed of sustainability.

43. Policy and institutional context for NRM in Kenya: Challenges and opportunities for Landcare.

44. Nina-Nina Adoung Nasional di So! Field test of rapid land tenure assessment (RATA) in the Batang Toru Watershed, North Sumatera.

45. Is Hutan Tanaman Rakyat a new paradigm in community based tree planting in Indonesia?

46. Socio-Economic aspects of brackish water aquaculture (Tambak) production in Nanggroe Aceh Darrusalam.

47. Farmer livelihoods in the humid forest and moist savannah zones of Cameroon.

48. Domestication, genre et vulnérabilité : Participation des femmes, des Jeunes et des catégories les plus pauvres à la domestication des arbres agroforestiers au Cameroun.

49. Land tenure and management in the districts around Mt Elgon: An assessment presented to the Mt Elgon ecosystem conservation programme.

50. The production and marketing of leaf meal from fodder shrubs in Tanga, Tanzania: A pro-poor enterprise for improving livestock productivity.

51. Buyers Perspective on Environmental Services (ES) and Commoditization as an approach to liberate ES markets in the Philippines.

52. Towards Towards community-driven conservation in southwest China: Reconciling state and local perceptions.

53. Biofuels in China: An Analysis of the Opportunities and Challenges of Jatropha curcas in Southwest China.

54. Jatropha curcas biodiesel production in Kenya: Economics and potential value chain development for smallholder farmers.

55. Livelihoods and Forest Resources in Aceh and Nias for a Sustainable Forest Resource Management and Economic Progress.

56. Agroforestry on the interface of Orangutan Conservation and Sustainable Livelihoods in Batang Toru, North Sumatra.

57. Assessing Hydrological Situation of Kapuas Hulu Basin, Kapuas Hulu Regency, West Kalimantan.

58. Assessing the Hydrological Situation of Talau Watershed, Belu Regency, East Nusa Tenggara.

59. Kajian Kondisi Hidrologis DAS Talau, Kabupaten Belu, Nusa Tenggara Timur.

60. Kajian Kondisi Hidrologis DAS Kapuas Hulu, Kabupaten Kapuas Hulu, Kalimantan Barat.

61. Lessons learned from community capacity building activities to support agroforest as sustainable economic alternatives in Batang Toru orang utan habitat conservation program 
62. Mainstreaming Climate Change in the Philippines.

63. A Conjoint Analysis of Farmer Preferences for Community Forestry Contracts in the Sumber Jaya Watershed, Indonesia.

64. The highlands: a shared water tower in a changing climate and changing Asia

65. Eco-Certification: Can It Deliver Conservation and Development in the Tropics.

66. Designing ecological and biodiversity sampling strategies. Towards mainstreaming climate change in grassland management.

67. Towards mainstreaming climate change in grassland management policies and practices on the Tibetan Plateau.

68. An Assessment of the Potential for Carbon Finance in Rangelands.

69 ECA Trade-offs Among Ecosystem Services in the Lake Victoria Basin.

69. The last remnants of mega biodiversity in West Java and Banten: an in-depth exploration of RaTA (Rapid Land Tenure Assessment) in Mount Halimun-Salak National Park Indonesia.

70. Le business plan d'une petite entreprise rurale de production et de commercialisation des plants des arbres locaux. Cas de quatre pépinières rurales au Cameroun.

71. Les unités de transformation des produits forestiers non ligneux. alimentaires au Cameroun. Diagnostic technique et stratégie de développement Honoré Tabuna et Ingratia Kayitavu.

72. Les exportateurs camerounais de safou (Dacryodes edulis) sur le marché sous régional et international. Profil, fonctionnement et stratégies de développement.

73. Impact of the Southeast Asian Network for Agroforestry Education (SEANAFE) on agroforestry education capacity.

74. Setting landscape conservation targets and promoting them through compatible land use in the Philippines.

75. Review of methods for researching multistrata systems.

76. Study on economical viability of Jatropha curcas L. plantations in Northern Tanzania Assessing farmers' prospects via cost-benefit analysis.

77. Cooperation in Agroforestry between Ministry of Forestry of Indonesia and International Center for Research in Agroforestry.

78. "China's bioenergy future. an analysis through the Lens if Yunnan Province.

79. Land tenure and agricultural productivity in Africa: A comparative analysis of the economics literature and recent policy strategies and reforms.

80. Boundary organizations, objects and agents: linking knowledge with action in agroforestry watersheds.

81. Reducing emissions from deforestation and forest degradation (REDD) in Indonesia: options and challenges for fair and efficient payment distribution mechanisms.

82. Mainstreaming Climate Change into Agricultural Education: Challenges and Perspectives

83. Challenging Conventional mindsets and disconnects in Conservation: the emerging role of eco-agriculture in Kenya's Landscape Mosaics.

84. Lesson learned RATA garut dan bengkunat: suatu upaya membedah kebijakan pelepasan kawasan hutan dan redistribusi tanah bekas kawasan hutan.

85. The emergence of forest land redistribution in Indonesia.

86. Commercial Opportunities for Fruit in Malawi.

87. Status of fruit production processing and marketing in Malawi

88. Preventing and identifying Scientific Fraud in Tree Science Research, with specific reference to World Agroforestry Centre (ICRAF) 
The World Agroforestry Centre is an autonomous, non-profit research organization whose vision is a rural transformation in the developing world where smallholder households

strategically increase their use of trees in agricultural landscapes to improve their food security, nutrition, income, health, shelter, energy resources and environmental sustainability. The Centre generates science-base knowledge about the diverse role that trees play in agricultural landscapes, and uses its research to advance policies and practices that benefit the poor and the environment.

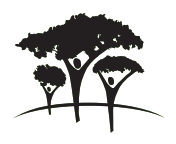

United Nations Avenue, Gigiri - PO Box 30677 - 00100 Nairobi, Kenya Tel: +254 207224000 or via USA +1 6508336645

Fax: +254207224001 or via USA +1 6508336646

www.worldagroforestry.org 